\title{
Discussion of the Bosworth and Poole Reports
}

SeVeral ParTICIPANTS QUestioned the use of traditional capacity utilization indexes for analyzing price movements. Alan Greenspan contended that the concept of capacity that is most relevant to price determination is the effective capacity that is available in a very short period of time. For example, a company may be operating at 80 percent of capacity, as measured by the McGraw-Hill index, but its capability of producing goods with a four-week lead time may be only 3 percent higher than its current rate of production. He suggested that we recognize that the McGraw-Hill capacity figures implicitly measure what is available to a particular company or industry, given the long lead time necessary to obtain the needed workers or materials and to get idle facilities into operation. Greenspan argued that order backlogs and the pace of new orders are more appropriate statistics for price analysis than is the level of capacity utilization. He pointed out that these order measures have risen rapidly and are at historically high levels in many industries.

Paul Samuelson related Greenspan's remarks to the proposition that prices are functionally related to both the level of output and its rate of change. In this sense, excess demand is an important part of recent price increases. But there is also hope that price pressures will ease once the present rate of output growth slows even if the labor market is still tightening and long-run excess capacity still dwindling. Saul Hymans reported that such an effect is found statistically if prices are regressed against a term that measures the interaction between capacity utilization and output change: Prices rise faster than unit labor costs if output grows very rapidly when operating rates are already quite high. Without high operating rates, rapid expansion does not have this effect. Walter Heller noted that demand 
in excess of speed limits and demand in excess of capacity called for different policy responses. In his view, temporary restraints on price increases are warranted when demand is temporarily advancing too rapidly and can serve until conventional macroeconomic policies can take over.

Lawrence Klein reported that, according to the Wharton indexes, capacity utilization rates in many industries were approaching the 1965-66 take-off point which led to serious inflationary pressures. He warned that some industries are already very close to capacity and that the situation will grow worse in the quarters to come. Arthur Okun was puzzled by the performance of aggregate capacity that indexes such as Wharton's implied. He noted that manufacturing output had grown only 10 percent in the four years through the first quarter of 1973. Capacity expansion must have been unusually small over this interval for capacity utilization now to be as tight as these measures report.

Samuelson argued that government agricultural policies were only partly to blame for the recent explosion in food prices. Heavy world-wide demand and supply problems that were not easily foreseeable have been important. He noted the expanding Japanese demand for meat, droughts in Asia and Australia, and snow cover failures in Russia as important factors in the supply-demand balance. But he pointed out that if commodity futures markets did not anticipate the price effects of these factors and the Russian wheat sales, we should not be too surprised that agricultural policy did not anticipate them either.

With world-wide demand as strong as it is, Lawrence Klein suggested, we face a new kind of tradeoff between the competing objectives of a favorable balance of trade and an increased supply of goods at home needed to head off domestic inflation. He preferred that we pursue export expansion, since each round of devaluation has contributed to our inflation and there is a pressing need to improve our payments balance in order to gain exchange stability. Alan Greenspan pointed out that strong world-wide demand had altered the effect of imports on our price level. Up until recently, foreign competitors obtained their import shares largely through price competition, thus putting a partial "lid" on domestic prices. But because the latest devaluation coincided with a massive increase in world demand, this lid has been lifted, resulting in a substantial price boost in a number of commodities, such as textiles.

R. J. Gordon offered a different perspective on the recent inflation. $\mathrm{He}$ referred to the last sector report he presented before the Brookings panel, in 
which he concluded that Phases I and II had a greater moderating impact on prices than on wages. At that time, he suggested that companies preferred to postpone their price increases rather than engage in costly fights with the Price Commission. He based this conclusion on the behavior of profit margins, which were below levels that he estimated should have prevailed at that phase of the business cycle. The recent price explosion resulted as firms attempted to reestablish profit margins that they regard as "normal" for this phase of the cycle.

Hendrik Houthakker focused on the reasons he believed the administration abandoned Phase II. Prices of food and raw materials were not controlled by Phase II, and increases in these areas gradually found their way into the general price level. Since Phase II represented an attempt to control the entire price level, the growing impact of increases in the prices of items outside the purview of Phase II forced the eventual collapse of the program. Houthakker agreed with Bosworth's analysis of the current problem in transportation. He criticized the long-standing policy of the Interstate Commerce Commission that grants general freight increases but does nothing to redirect available boxcars toward those who most need them. Bosworth's recommendation to allow greater flexibility in transportation rates, in his opinion, would to a large extent mitigate the crisis.

Samuelson questioned the case against controls implicitly argued in William Poole's paper. Simply stated, the case implies a law of conservation of price increase: If prices are controlled for a while, they make up for it by rising faster when controls are removed. The longer they are controlled, the more they deviate from what they otherwise would have been and the larger the price bulge that will follow. He saw no reason to accept such a view, which ignored many realities of price determination. With cost-push elements in the picture, prices rise because they are rising and not in any mandatory relation to measures of excess demand; therefore controls may hold prices and costs in general below the level to which they would otherwise go. In particular, he argued that monetary policy would be different with and without controls, so that, even granting a loose relationship between the money stock and the price level, the money stock would be at a lower level after controls than it would have been without them and with more inflation. Concerning recent events, he thought it plain that controls were abandoned at the wrong time, precisely when the rapid advance in demand was exerting its greatest pressure on prices. 